\section{RECENT ADVANCES IN PHYSIOLOGY}

By W. H. Newton, M.D., M.Sc. (Manch.), D.Sc. (Lond.), Professor of Physiology, University of Edinburgh. Seventh Edition. Pp. 268 with 90 illustrations. London : J. \& A. Churchill Ltd. I949. 2 Is. net.

It is with very mixed feelings that we welcome the most recent edition of 'Recent Advances in Physiology,' by Professor Newton, because, as everyone knows, this is the last book that he wrote. A great, a kindly and an inspiring man, he died just as he was appointed to the important chair in physiology at the University of Edinburgh. My task here, however, is not to write of Newton but of 'Recent Advances,' because prospective readers will naturally want to know if the book is a success, what it contains and if it is clearly and interestingly written. It is points such as these which must be referred to here.

Somewhat shorter than its predecessors this new edition contains ten completely new chapters which cover a wide range of physiological science : Chapter I, The Physical Basis of Temperature Regulations; Chapter II, Water Diuresis; Chapter III, Digestion; Chapter IV, Some Aspects of the Physiology of Pregnancy; Chapter V, Blood Pressure and the Kidneys (with I. Calma); Chapter VI, Catheterization of the Heart; Chapter VII, The Electrical Excitation of Nerve; Chapter VIII, Cutaneous Sensation; Chapter IX, Auditory Impulses; Chapter X, Colour Vision. The reader will notice that three of these deal with the special senses and are particularly welcome. The chapter on colour vision is very much to the point and should be read by all who are interested in this subject.

The style is lucid, the descriptions are clear, the selection of subjects excellent, and the long lists of references more than useful. It goes without saying that the book is well printed and bound, and that it preserves the high standard laid down by previous books in the 'Recent Advances' series.

\section{DISEASES OF WOMEN}

By Ten Teachers. Edited by Clifford White, M.D., F.R.C.P., F.R.C.S., F.R.C.O.G., FranK Cook, M.B., F.R.C.S., F.R.C.O.G., and SIR WILliam GilliatT, K.C.V.O., M.D., M.S, F.R.C.P., F.R.C.S., P.R.C.O.G. 8th Edition. Pp. viii $+46 r$, with 170 illustrations and I plate. London: Edward Arnold \& Co. 1949. 25 s.

It is seven years since the appearance of the last edition of this well-known book. There are three newcomers in the list of contributors-Humphrey Arthure, Arthur Bell and Frederick Roques, in place of Mr. Victor Bonney, Mr. Goodwin and the late Sir Comyns Berkeley. Each of the ten authors has been given a section of the book to revise and it can easily be seen that great attention has been paid to collaboration. The editors are to be congratulated on this fine example of collective authorship.
This book will certainly be as popular as ever. The chapters are short, the material is well arranged and there are ample clear illustrations. It is comprehensive and includes good chapters on backache, disorders of micturition, neurasthenia in relation to pelvic disorders and contraception. Advances in endocrinology have not been forgotten. The chapter on the physiology of the endocrine glands has been completely rewritten and the chapters on disorders of menstruation are very adequate.

This old favourite can be strongly recommended. The undergraduate will find all that he requires clearly written, illustrated and at low cost. The general practitioner can obtain sound practical advice on diagnosis and treatment with little effort. The postgraduate can benefit by the considered opinion of ten of London's well-known teachers of gynaecology on a large variety of problems.

I.J.

\section{THE COMPARATIVE ANATOMY AND PHYSIOLOGY OF THE LARYNX}

By V. E. Negus, M.S., F.R.C.S. Pp. xix +230 , with I9I illustrations. London: William Heinemann. 1950. 30s.

Twenty years ago Mr. Negus placed before the public his encyclopaedic work on the mechanism of the larynx. The work included the record of his dissections of the larynx in a great many members of the animal world, and of his conclusions as to the evolution and function of that organ. Mr. Negus's $\leq$ interest in the subject has never flagged, and he hase continued to make dissections and to study the? action of the larynx in innumerable species. $\mathrm{He}$ has made a number of further communications on the subject, and the present volume, though much smaller, is not just an abridged edition of the former. It presents a more completed view of the matter, and includes an epitome rather than the bulk of the evidence upon which the views are based. Chapters are included on the modification of the upper air passages for the purposes of olfaction, of deglutition, of phonation and of the various aspects of respiration.

Two chapters discuss the production of sound in its relation to the sense of hearing, and as a means of communication, and the author arrays his facts so as to tell a most entrancing story of the beginnings of audible communication in animals, birds, fishes and insects, and its gradual development to a state of comparative perfection in man.

A final and most erudite chapter on the anatomy of the human larynx adds great value to this comparative study of the larynx. Mr. Negus obviously subscribes to the Chinese saying that 'one picture is worth a million words,' as in the 230 pages of the book there are 191 plates, most of which include several separate drawings. Many of these are from the capable pen of Mrs. Negus, including several plates of animals drawn to indicate their various modes of auditory communication.

This book should not be put away on the bookshelf but kept on the table for frequent reference. F.C.O. 